\title{
DETERMINANTS OF EFFECTIVE TALENT MANAGEMENT
}

\author{
Ewelina Wilska \\ Faculty of Economic Sciences and Management, \\ Nicolaus Copernicus University, Toruń, Poland, \\ e-mail: ewilska@umk.pl
}

\begin{abstract}
Purpose: The main goal of this article is to present effective ways of talent management in an enterprise.

Methodology: Factors identification was carried out based on analysis of subject literature, and also on empirical research, which were carried out within the framework of doctoral dissertation. On the basis used of expert method inspired by Delphic technique, opinions received from the management experts allowed the determinants to be divided with regard to their positive and negative influence and ability to develop an enterprise, namely internal and external.

Findings: Talent management is gaining strategic meaning for enterprises, which aim to secure competitive advantage, not only by dynamic growth. Employers' skills in terms of extracting, adjusting and appreciating creativity, and potential to develop knowledge, abilities and experience of employees can stand up to requirements which are made in the days of economy based on knowledge.

Implications: Effective talent management is conditioned by numerous factors. Taking into consideration opinions of experts participating in the research, conditions were divided into their positive and negative influence, and the ability of shaping them by a company, namely internal and external. The author is expressing hope that analysis of determinants of effective talent management will be an interesting and useful reading from a perspective of talent management in the both academic and practical dimension, even though it is only a starting point for further discussion.
\end{abstract}

Keywords: talent, talent management, effective talent management, potential to development

Paper type: Research paper

\section{Introduction}

Individuals, whose competencies supported by solid base of knowledge and experience are rare goods, constitute a certain kind of guarantee that the strategy of an organisation will be efficiently implemented (Listwan, 2010). Failure to satisfy the needs and aspirations of workers who contribute to the company's development is very often the reason for changing their workplace. This is why, companies face the dilemma of talent management.

The main goal of this article is to present effective ways of talent management in an enterprise. Effective management is determined by numerous 
DETERMINANTS OF EFFECTIVE TALENT MANAGEMENT

Ewelina Wilska factors, both positive and negative. Their identification was carried out based on analysis of subject literature, and also on empirical research, which were carried out within the framework of doctoral dissertation. On the basis of expert method inspired by Delphic technique, opinions received from the management experts allowed the determinants to be divided with regard to their positive and negative influence and ability to develop an enterprise, namely internal and external. In the research used the knowledge and experience of four scholars and six practitioners, including: four HR Directors, one representative of HR Director, and one HR consultant, who was also a head-hunter and the owner of an HR consulting company.

\section{Talents and talent management}

Polish and foreign literature provides a lot of definitions of the term 'talent', which describe it from different perspectives. Michaels et al. (2001) present talent from an individual angle as: "the sum of certain person's abilities - their innate gifts, skills, knowledge, experience, intelligence, judgements, attitude, character and resourcefulness. It also contains the ability to learn, and self-improvement". Listwan (2010) focuses on the individual aspect as well, and points that: "by talent we need to see a person with an outstanding potential". The second group of definitions involves such, in which the authors concentrate on organisational perspective. Borkowska (2005) defines talents as persons who are: "creative, resourceful, of high development potential, which make up a mainspring for company's value growth". According to Ingram: "a talent is a person who is characterised by potential, abilities, motivation and knowledge, whose actions significantly influence the way an organisation functions, who achieves above average results and consigned goals, at the same time caring for their own personal development" (Ingram, 2011). Cheese et al. (2008) indicate, that in terminology of a talent, several attributes can be specified, namely knowledge, experience, skills and behaviours, which a certain individual possesses and contributes to their work. However, from the business perspective, the most important is formulated by a company's willingness to acquire, retain and develop these human resources, which are indispensable for coping with business goals.

Upon attempting to grasp the term, some of the authors consider if it is addressed to all or selected individuals, rather than within individual or organisational perspective. Armstrong (2011) supports the group which attributes a potential talent to everybody. He expresses an opinion that every employee has abilities, therefore the process of talent management should not be limited only to a small group of workers. He also emphasizes that actions should be focused on individuals who possess rare skills and present a considerable potential to succeed. Similarly, Juchnowicz (2007) claims, that all employees who have key and specialist competencies desired in a particular organisation, should be treated 
as talents. The opposing group is formed by authors, who, just like Berger stress that talents are: "a very small group of individuals demonstrating above average achievements, inspiring others to reach above average results, understanding key competencies and the value of an organisation. Losing people from this group or their absence causes limitation of organisational development due to their disproportionate influence on present and future results of the organisation" (Berger, 2004). According to Jabłoński (2009): "talents cause that particular workers are capable of using and expanding competencies and generating a unique merit in an organisation in a more effective way".

Resulting from the course of research, the first part contains synthesis of answers provided by respondents in the survey's questionnaire, and thus, effort to define the term 'talent' was made. Therefore, a talent is an individual, who possesses interpersonal abilities and potential for developing knowledge, capabilities and experience for a company's good. In the second part of the research, the author had the possibility to ask experts chosen from among renown Polish scholars in the field of management and HR practitioners, about their most suitable definition of 'talent' in Polish conditions. After compiling their views, the following definition was eventually worked out: a talent is an individual displaying potential and predispositions to continuous development of competencies, deriving satisfaction from work, which results in attainable benefits for an organisation.

As for the term 'talent', literature provides a lot of views on talent management, different from each other in terms of expressing issues concerning particular constitutive elements of managing talents and its place in an organisation (Brittain, 2007; Davis et al., 2007; Bieniok, 2008; Iles et al., 2010).

Looking from the perspective of a talent relating to all employees, it needs to be taken into consideration that in such case, managing talents does not differ from managing human resources (HRM), in this sense that: "managing talents encompasses a set of typical HR actions, such as recruitment, selection, training and evaluation" (Iles et al., 2010). Lewis and Heckman (2006) add in the same context that managing talents: "serves to change the quality of HR practices in order to maintain their actions, new and fresh on the surface, but it does not develop our knowledge about strategic and effective talent management".

In connection to the elite interpretation of talent by Iles et al. (2010) it is considered that the same tools can be used in talent management as in managing human resources, however, the focus should be put on relatively small part of employees described as talents, on account of their present situation and future potential. Brittain (2007) emphasises the necessity of concentrating structures, processes and people on workers with high potential, who achieve high results, and have promotion prospects. Listwan (2010) presents a similar approach, which defines talent management as: "a series of actions towards outstandingly gifted 
DETERMINANTS OF EFFECTIVE TALENT MANAGEMENT

Ewelina Wilska individuals, which are taken with intention to develop these individuals to achieve organisation's goals".

Many a time, the interpretation of talent management in the subject literature is given in the form of a process, and respective elements are enumerated. ING may serve as an example; managing talents for representatives of this company includes (Maślanka, 2005): talent identification, their development, plans for their succession to the highest positions in the company and searching and selecting individuals for free positions. Borkowska (2007) claims that key aspects are: acquiring talents, their retention, development and motivation. According to Heinen and O'Neill (2004), managing talents: encompasses an array of interconnected actions of managing staff, concerning: identification, attraction, integration, development, motivation and employee retention".

All the presented above concepts of talent management differ from each other in respect to the accuracy of particular stages and interpretation of certain terms. Sienkiewicz (2007) states that a slightly extended set of tasks is indispensable for effective talent management, namely employment planning, selection, retention (motivational systems included), potential development, work assessment and career planning. It is worth mentioning that every stage of the process of talent management requires taking a series of actions, consistent for the whole organisation. Therefore, it is crucial to attribute responsibilities on respective levels, which would indicate tasks essential for executing the adopted strategy in a proper way. Accordingly, it seems necessary to define subjects participating in the discussed TM process, together with a clear assignment of duties.

\section{Research methodology}

Effective management is determined by numerous factors, both positive and negative. Their identification was carried out based on analysis of subject literature, and also on empirical research, which were carried out within the framework of doctoral dissertation.

On the beginning conducted CAWI (Computer-Assisted Web Interview) technique among a group of 64 companies selected from the biggest enterprises in Poland. Dissertation contains information from the database of companies from the List 2000 of "Rzeczpospolita", published in 2011. The content criterion of enterprise selection was the availability of information concerning employment in certain entities. That is why, the number of population, which was the starting point for further analysis, amounts to 1047 companies.

The research brought results, based on which, inquiries to experts chosen from among the most prominent management scholars and HR practitioners were formed. There was used of expert method inspired by Delphic technique. The key role of the expert method, which was inspired by Delphi, the use of 
teamwork plays knowledge, experience and opinion of experts in the field of working independently. Experts have been selected among the "eminent experts substantive issues related to the subject of research" (Stankiewicz, 1988).

It is worth emphasizing that invitation to participation in the research was

DETERMINANTS OF EFFECTIVE TALENT MANAGEMENT Ewelina Wilska sent to a bigger number of specialists, however, in the end the research used the knowledge and experience of four scholars and six practitioners, including: four HR Directors, one representative of HR Director, and one HR consultant, who was also a head-hunter and the owner of an HR consulting company, i.e.:

1) Tomasz Klisiewicz - HR Director at Trigon Dom Maklerski,

2) Joanna Jurek - HR consultant, who was also a head-hunter and the owner of an HR consulting company Golden HR,

3) Katarzyna Gadomska-Lila - Doctor, Assistant Professor in the Department of Organization and Management, University of Szczecin,

4) Stefan Lachiewicz - Professor, an employee of the Department of Management University of Lodz,

5) Przemysław Płachetka - HR Director at Polpharma,

6) Aleksy Pocztowski - Professor, Head of the Department of Human Capital Management Cracow University of Economics,

7) Agnieszka Sajewicz - representative of HR Director at TZMO,

8) Czesław Zając - Professor, research and teaching employee the Department of Economics and Organization of Enterprises and the Department of Human Resource Management School of Banking in Wroclaw,

9) Robert Zelewski - HR Director at McCormick\&Company,

10) Andrzej Zieliński - HR Director at Neuca Group.

On the basis of expert method inspired by Delphic technique with one feedback information received from the management experts allowed author the determinants to be divided with regard to their positive and negative influence and ability to develop an enterprise, namely internal and external.

\section{Internal conditions of effective talent management}

Internal conditions of effective talent management are illustrated in Figure 1.

The element having essential influence on effectiveness of the management process in an enterprise is its managerial staff, indicated as $70 \%$, by experts who participated in the research. Herein, it should begin with a high awareness of chief executives in relation to the possibility of building competitive advantage based on 'the abundance of talents', in other words, appreciating human capital in an organisation. Growing awareness of the executives, concerning the significance of TM programmes translates into the increase of their involvement and determination to provide support both, in the context of direct participation, and creating a budget adequate to the goals. 
DETERMINANTS OF EFFECTIVE TALENT

Figure 1.

Internal conditions of effective talent management

Source: self-reported data based on research results. MANAGEMENT

Ewelina Wilska

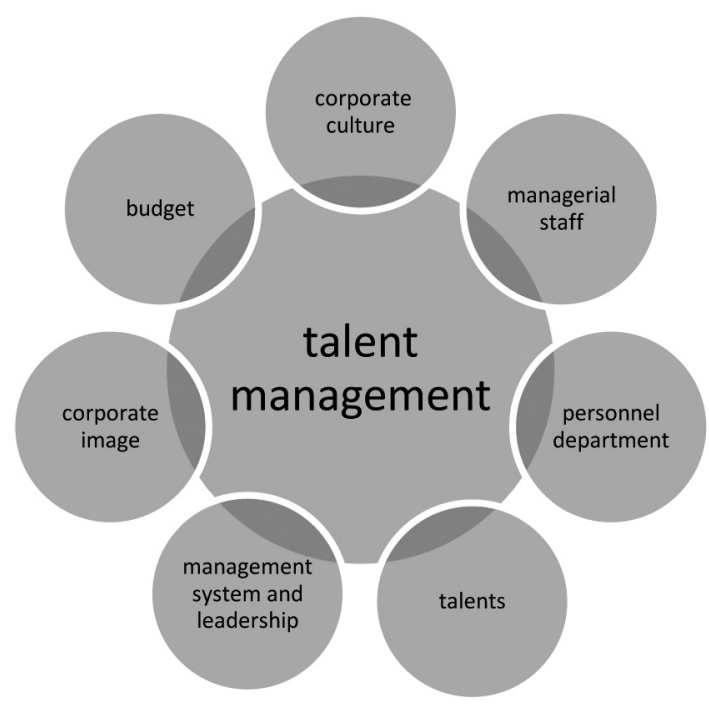

The research presented three records of the experts, emphasising the importance of junior managers. It is equally important to engage line managers in talent development programmes, especially because of their direct contact with gifted employees. Motivating, selecting and delegating duties adjusted to a worker should also be enumerated here. A special attention was paid to the role of managers who take part in a "job shadowing" programme. It is important for them to possess coaching skills in order to guide a talented individual not only as a mentor, showing solutions. It is crucial to allow to independently deal with new situations, problems, setting goals and pursing them under the guidance of a coach, staying in a relationship based on partnership and trust.

Personnel department also plays an important role in the context of effective talent management. Effective functioning of personnel units dealing with human resources is possible owing to the work of highly qualified HR specialists, this having been marked by three experts in the research. Consequently, it is vital to possess competencies in diagnosing prominent workers. Knowledge of these competencies is important for assessing the possibilities and the course of development of certain individuals.

According to three other experts, corporate culture which promotes learning fosters the development of human capital. Involvement of managerial staff on all levels into development of talents has a huge impact on the whole corporate culture. Additionally, and most of all, communication is essential for effective talent management. What plays an important role in the matter of constant 
communication is conducive to creating a good atmosphere in an organisation and conveying values, which are essential from the enterprise's perspective, and which facilitate maintaining employees' loyalty.

Within the framework of internal condition category, presented in the figure as talents, two experts mentioned possessing a large resource of valuable workers. What is favourable when effective talent management is concerned, is having a resource base of people with high level of abilities and ready to develop their competencies, which is vital form the angle of goals set by an organisation.

Management requires implementing a lot of procedures. Those, which positively influence effective talent management are generally formulated as the system of management and leadership in an organisation. Here, a proper personal strategy which guarantees adequate development and suitable use of talented employees, can be mentioned. Another thing are procedures and traditions (reference to corporate culture) in the range of professional selection of successor staff or so called managerial staff. What follows is adjusting the remuneration system to tasks and competitive ones. The next thing is development by implementing programmes connected with guiding a talent in the form of a coach or internal and/or external mentor.

As four experts state, having an adequate budget assigned for TM programmes facilitates effective management. This aspect is crucial from the point of view of the whole process, e.g. Employer branding actions inside, and also outside. The significance of the budget size is important because of high cost of development programmes.

When analysing internal conditions facilitating effective talent management, one cannot pass over the fact that increasing pressure on effectiveness creates a chance that efficient solutions in the area of talent management will "defend themselves", regardless of the awareness level of the management and HR department in this respect.

Within the corporate image element, which is discussed as the factor influencing effective talent management, maintaining good contact with universities, research centres, consulting and training companies was included. Besides, three expert indications pointed out drawing attention to corporate image in the context of clear and readable organisation's mission.

Occurrence of internal conditions which inhibit effective talent management is worth mentioning. Analogically to favourable internal conditions, they may include managerial staff, particularly in the context of awareness of the importance of talent management issues, among a managerial staff, including the board and the owners of enterprises. Marginalising the investment in people and not perceiving human capital as the factor which, in the long term influences the company's results, may cause non-optimal use of workers' potential and difficulties in attracting and retaining talents in the company. In the opinion of the 
DETERMINANTS OF EFFECTIVE TALENT MANAGEMENT

Ewelina Wilska experts, lack of support of management, resulting from underestimation of the significance of 'talent resources' possession is also present in junior executives. Inappropriate managerial staff that present no understanding and involvement are not able to manage talents in an effective way.

An additional inhibiting condition on the management part is its reluctance to engage in long-term plans, as indicated by 5 experts.

Budget was named definitely more often ( 7 indications) in inhibiting conditions rather than in favourable ones. Effective talent management is an investment which requires spending more managers' and personnel department workers' time, and financial resources. Budget limitations have a bad influence on the possibility to manage talents effectively. Bad economic and financial state interacts with outside employer branding actions, such as creating additional workplaces for interns to be able to pick out the most promising individuals. Limited companies' budgets and, at the same time, high costs of development programmes decrease the opportunity to acquire talented workers and provide their proper development.

Low level of professionalism of the personnel department is the thing which significantly impedes, and many a time makes TM process impossible. Lack of communication and co-operation between the departments of a certain organisation make bad atmosphere to arise. It was also pointed here that a negative impact of corporate culture which promotes egalitarianism - treating everyone as equals, can lead to unwillingness to prove oneself and to sustain additional efforts of the best ones.

When considering programmes which inhibit effective talent management we can mention ineffective staff motivating system which promotes mediocrity and conformism in workers' actions. Another one is lack of staff development policy, including also the procedures of identifying the most talented. Additionally mentioned was excessive formalisation of HR processes which enables manifesting creativity and independence in employees' work. What was also pointed at was the lack of organisational abilities to use talents properly, and, resulting from a low budget, poor pay policy. It is worth emphasising the primary condition for inhibiting effective management, namely no programmes at all. It can be particularly seen in the aspect of e.g. promotion, when networking, cliques, and other informal actions are decisive in terms of promotion and awards for, so called, 'one of us', and not for talented workers, who are important from the company's perspective.

Additionally, apart from conditions analogic to the favourable ones, we can add to the inhibiting ones a big turnover of talented staff, resulting from unclear communication, lack of vision and development directions, lack of consistency in actions, and mobbing (lack of consistent corporate culture). Many a time, as particularly emphasised by two experts, corporations face the problem of excessive 
expectations of talents and manifesting their superiority. What is more, elitist attitude intensifies occurrences of jealousy or lack of cooperation.

\section{External conditions of effective talent management}

Effective talent management is influenced not only by the conditions a company can have effect on. One cannot forget about external conditions, namely the ones which can be found outside an organisation. Factors of micro-environment can be mentioned here, i.e.: local community, competition, clients, as well as factors of macro-environment, i.e.: legal, economic, and cultural conditions. External conditions which influence effective talent management are presented in Figure 2.

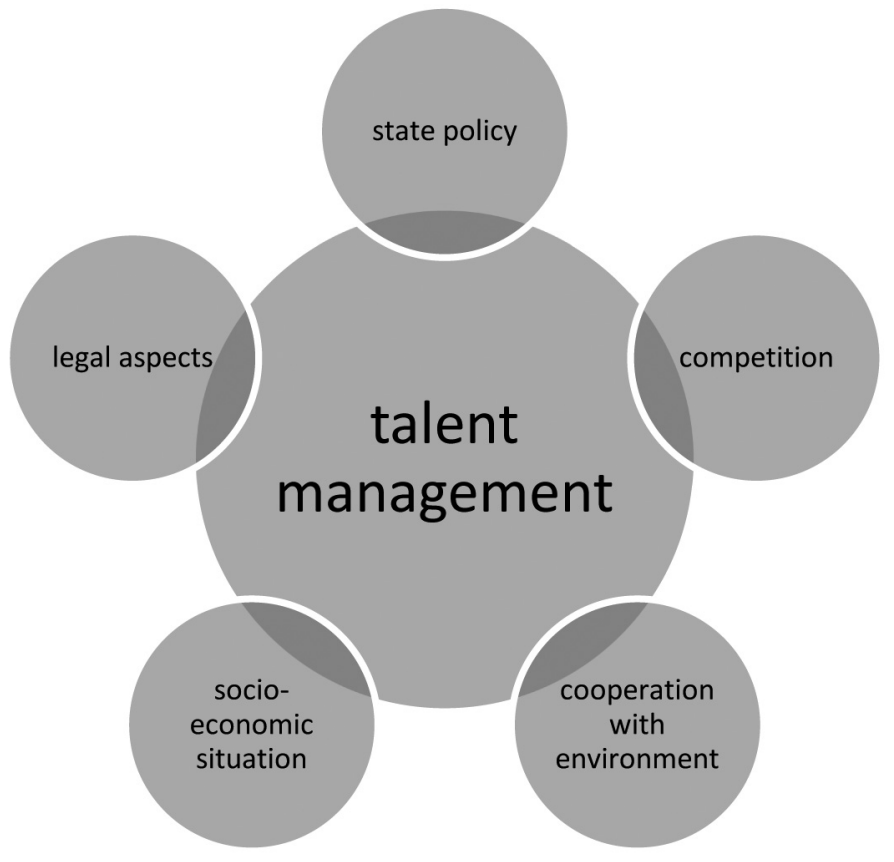

External conditions which are conducive to effective talent management include socio-economic situation. Here, we can mention the globalisation of economy, and resulting from it inflow of international organisations to Poland, which possess developed systems of talent management. It was shown, that emphasising more and more often the meaning of management programmes and their effects, e.g. in trade press, and indicating best practices is also significant. It can be explained by a peculiar trend for managing talents. A positive influence towards development of knowledge absorptive sectors is caused by structural changes in economy. In addition, social recognition and respect for the talented
Figure 2.

External conditions of effective talent management

Source: self-reported data based on research results. 
DETERMINANTS OF EFFECTIVE TALENT MANAGEMENT

Ewelina Wilska positively affect the perception of the whole process, which has a great impact on its effectiveness. Relating to the three experts' indications, employees' mobility needs to be mentioned. On one hand, it will be favourable, concerning the possibility of acquiring or delegating a talented worker from or to a distant place in comparison with the starting point. On the other hand though, the bigger the worker's mobility, the bigger the chance of quitting a job. However, in all these situations, taking into account mobility in the process of talent management will influence its effectiveness.

Cooperation with environment has a substantial impact, emphasised by five experts. First of all, there is an actual willingness of collaboration between a higher education institution and a business. Secondly, development of colleges and universities, as well as foundations and associations is directed towards supporting the talent management process. Thirdly, there is cooperation with a growing number of companies providing services on a high level, which support managing talents in companies. Assistance in employer branding actions, and also creating recruitment systems, and employee appraisal systems etc. is on a higher and higher level and more easily accessible.

Political and legal aspects are favourable in terms of being conducive to talent management when a real government's endorsement exists. State policy which promotes companies generating resourcefulness and technological development, and regional policy in the context of efficiency of talented staff growth are also indicated. Next, as emphasised by two experts, labour legislation favours creating workplaces dedicated to individuals possessing above average abilities, or, owing to facilitating development initiatives for employees, as indicated by four experts.

The last but not least condition mentioned, is competition, pointed out by six experts. It will be presented as market competition from the perspective of an enterprise functioning in a certain line of business. What is important at this point, is the increase in the importance of the innovation in how companies function. Outstanding employees, who are fought for, have influence on inventiveness, and therefore, the struggle to acquire talents has a great impact on effectiveness of talent management process. What is significant here, is the number of talented individuals on the job market, with consideration to possessing particular, typically specific competencies. It is definitely easier and talent management is more effective in a situation when there are a lot of talents with certain requirements, and very few job offers. However, the situation is most often the opposite.

Thus, it is necessary at this point to recognise external conditions which inhibit talent management. It is beyond all doubt that reversing favourable external conditions creates inhibiting external conditions, what has been emphasised by the experts. It is particularly worth stressing in this part the low involvement of some schools and universities, which treat the actions of employer branding as sources 
of additional income and not as expansion of education offer. When referring to universities, inappropriate level of teaching students was pointed out by three experts, together with the lack of sufficiently developed environment for creating the basis for personnel growth, such as: foundations, associations, and employer organisations.

Additionally, unfavourable socio-economic conditions are marked by two experts, who claim that these are responsible for poor economic situation, economic crisis and regress in the activity of companies which are inclined towards reducing costs and investments on human capital. According to two more experts, turbulent environment and macroeconomic instability influence restricting of mid and long term planning. In addition, miasma in socio-economic environment, e.g. undermining the role of higher education by politicians and business people, has a negative impact too.

Unfavourable state policy and the lack of formal and legal solutions which would encourage to invest in human capital also affect talent management in an unfavourable way. Another inhibiting condition is the feeling of hopelessness of inhabitants of certain regions of Poland. Similarly, unjustified lack of faith in human potential, or too big a pressure on educated and talented individuals moving out of Poland to work in other countries (as indicated by three experts), have a negative influence.

\section{Conclusion}

Effective talent management is conditioned by numerous factors. Taking into consideration opinions of experts participating in the research, conditions were divided into their positive and negative influence, and the ability of shaping them by a company, namely internal and external.

Talent management is gaining strategic meaning for enterprises, which aim to secure competitive advantage, not only by dynamic growth. Employers' skills in terms of extracting, adjusting and appreciating creativity, and potential to develop knowledge, abilities and experience of employees can stand up to requirements which are made in the days of economy based on knowledge. Undoubtedly, talents are becoming a pillar of an organisation functioning in a variable environment of $21^{\text {st }}$ century economy.

\section{References}

Armstrong, M. (2011), Armstrong's Handbook of Strategic Human Resource Management, Kogan Page, London.

Berger, L.A. (2004), "Creating a Talent Management System for Organization Excellence: Connecting the Dots", in: Berger, L.A., Berger, R.B. (Ed.), The talent management handbook. Creating organizational excellence by identifying, developing, and promoting your best people, McGraw-Hill, New York, pp. 3-21. 
DETERMINANTS OF EFFECTIVE TALENT MANAGEMENT

Ewelina Wilska
Bieniok, H. (2008), 'Zarządzanie talentami jako źródło wiedzy i kompetencji w organizacji”, in: Glińska-Neweś, A. (Ed.), Zarządzanie organizacjami w gospodarce opartej na wiedzy. Zasobowe podstawy funkcjonowania i rozwoju organizacji, Wydawnictwo Dom Organizatora, Toruń, pp. 409-422.

Borkowska, S. (2005), "Kilka refleksji tytułem wstępu", in: Borkowska, S. (Ed.), Zarzadzanie talentami, Wydawnictwo IPiSS, Warszawa, pp. 11-13.

Borkowska, S. (2007), "O jakości zarządzania talentami”, in: Pocztowski, A. (Ed.) W kierunku kapitału ludzkiego, Wydawnictwo IPiSS, Warszawa, pp. 5-8.

Brittain, S. (2007), "How to manage key talent", People Management, Vol. 13 No. 12, pp. 46-47.

Cheese, P., Thomas, R.J., Craig, E. (2008), The talent powered organization: Strategies for globalization, talent management and high performance, Kogan Page, London.

Davis, T., Cutt, M., Flynn, N., Mowl, P., Orme, S. (2007), Talent Assessment: A New Strategy for Talent Management, Aldershot: Gower, England.

Heinen, J.S., O’Neill, C. (2004), "Managing Talent to Maximize Performance", Employment Relations Today, Vol. 31 No 2, pp. 67-82. DOI: http://www.dx.doi.org/10.1002/ ert.20018

Iles, P., Chuai, X., Preece, D. (2010), “Talent Management and HRM in Multinational companies in Beijing: Definitions, differences and drivers", Journal of World Business, Vol. 45 No 2, pp. 179-189. DOI: http://www.dx.doi.org/10.1016/j.jwb.2009.09.014

Ingram, T. (2011), "Miejsce i znaczenie talentów we współczesnej organizacji”, in: Ingram, T. (Ed.), Zarzqdzanie talentami. Teoria dla praktyki zarządzania zasobami ludzkimi' Polskie Wydawnictwo Ekonomiczne, Warszawa, pp. 17-19.

Jabłoński, M. (2009), Kompetencje pracownicze w organizacji uczacej się. Metody doskonalenia i rozwoju, Wydawnictwo C.H. Beck, Warszawa.

Juchnowicz, M. (2007), ’Założenia procesu zarządzania talentami w organizacji wiedzy", Edukacja Ekonomistów i Menedżerów, Vol.5 No. 1, pp. 21-29.

Maślanka K., Skudlik T. (2005), "ING inwestuje w talenty", in: Borkowska S. (Ed.), Zarządzanie talentami, Wydawnictwo IPiSS, Warszawa, pp. 137-146.

Michaels, E., Handfield-Jones, H., Axelrod, B. (2001), The War for Talent, Harvard Business School Press, Boston.

Lewis, R.E., Heckman, R.J. (2006), “Talent Management: A critical review”, Human Resource Management Review, Vol. 16 No. 2, pp. 139-154. DOI : http://www.dx.doi. org/10.1016/j.hrmr.2006.03.001

Listwan, T. (2010), "Zarządzanie talentami - nowy nurt zarządzania kadrami w organizacjach", in: Jagoda, H., Lichtarski, J. (Eds.), Kierunki i dylematy rozwoju nauki i praktyki zarządzania przedsiębiorstwem, Wydawnictwo Uniwersytetu Ekonomicznego we Wrocławiu, Wrocław, pp. 20-27.

Sienkiewicz, Ł. (2007), "Praktyczne rozwiązania w dziedzinie zarządzania talentami”, Edukacja ekonomistów i menedżerów, Vol. 5 No. 1, pp. 31-45.

Stankiewicz, M.J. (1988), Metody inwentyczne $w$ rozwiąywaniu problemów strategicznych przedsiębiorstwa przemystowego, Wydawnictwo UMK, Toruń. 